\title{
Naphthyl acetate esterase in the green rice leafhopper, Nephotettix cincticeps UHLER, with special reference to the resistant colony of the organophosphorus insecticide.
}

\author{
Kozaburo OzAKI and Hisayoshi KoIKe \\ Section of Phytopathology and Entomology, National Institute of Agricultural Sciences, Tokyo
}

\section{INTRODUCTION}

The green rice leafhopper, Nephotettix cincticeps UHLER, had been well controlled by malathion in Kochi Pref. since 1953, but in 1961, it was reported that malathion failed to control in some parts of Kochi Pref. Ozaki found that the leafhopper had developed a malathion resistance in Ōsone area. By later tests on the susceptibility to malathion and methyl parathion, it was authenticated that the marathion or methyl parathion resistance colony inhabited various areas of Japan (OzAKI, in press). OzAKI and Kurosu (in press) demonstrated also that the malathion and methyl parathion resistant colonies crossed to some other organophosphorus insecticides. In consideration of the above results, the attention is concentrated on the biochemical mechanisms in the development and genetics of insecticide resistance in the leafhopper.

Kojima et al (1963) investigated the biochemical mechanisms of development of the resistance to malathion and found that the increase in the activity of carboxyesterase was a cause of the development of resistance, but the cholinesterase activity and susceptibility of the esterase to malaoxon were not connected with the development of malathion resistance.

The primary objective of this study is to assay of the esterase in the leafhopper with an aid of $\beta$-naphthyl acetate as substrate, and to examine the difference between the esterase activity in susceptible and organophosphorus insecticide resistant leafhopper.

\section{MATERIALS AND METHODS}

Insects The eggs or larvae of the leafhopper were collected from Konosu, Soka and Kasukabe in Saitama Pref. and Koga in Ibaraki Pref. where the total amounts of insecticides which had been used to control the rice pests were very little, and from Ösone in Kochi Pref., Nakagawahara in Ehime Pref., Okayama in Okayama Pref. and Oyama in Tochigi Pref., where the leafhopper had been known develop resistance to organophosphorus insecticide. The eggs or larvae collected were reared under sixteen hours illumination at $25^{\circ} \mathrm{C}$. The larvae and adults were used throughout the experiments.

Enzyme solution Whole homogenates were prepared by homogenation of the insects in definite volumes of phosphate buffer (M/15, $\mathrm{pH} 7.0)$ using glass homogenizer of Potter-Elvehjem type. The resultant homogenate was centrifuged for $5 \mathrm{~min}$ at $3500 \mathrm{r.p.m}$. at $4^{\circ} \mathrm{C}$, and the supernatant was used as enzyme solution.

Substrate solution $\beta$-naphthyl acetate (Tokyo Kasei Co.) was used as substrate. The substrate solution was prepared as follows. Ten $\mathrm{mg}$ of the $\beta$-naphthyl acetate was dissolved in $2 \mathrm{ml}$ of aceton and added to $50 \mathrm{ml}$ of the phosphate buffer of $\mathrm{pH} \mathrm{7.0,}$ then filled to $100 \mathrm{ml}$ with distilled water.

The experimental procedures followed the method of Nachlas and Seligman (1949) with slight modification. After preincubation of substrate solution for $5 \mathrm{~min}$., $5 \mathrm{ml}$ of this solution and $1 \mathrm{ml}$ of the enzyme solution were incubated for $5 \sim 20 \mathrm{~min}$ at

(Received for publication, January 14, 1965) 
$37^{\circ} \mathrm{C}$. At the end of the incubation period, $1 \mathrm{ml}$ of the solution containing $4 \mathrm{mg}$ of naphthanil diazo blue B (Tokyo Kasei Co.) was added and well shaken. After a few min., $1 \mathrm{ml}$ of 40 per cent trichloroacetic acid was added. The coupled diazotized red color was extracted with $10 \mathrm{ml}$ of ethyl acetate. After centrifugation at 3500 r.p.m. for $5 \mathrm{~min}$., absorbance of ethyl acetate extract was measured by colorimetric method with a $540 \mathrm{~m} \mu$ filter.

\section{RESULTS}

Standard curve for the determination of $\beta$-naphthol The relation between the amount of $\beta$-naphthol liberated by the esterase action and the absorbance at 540 $\mathrm{m} \mu$ are shown in Fig. 1.

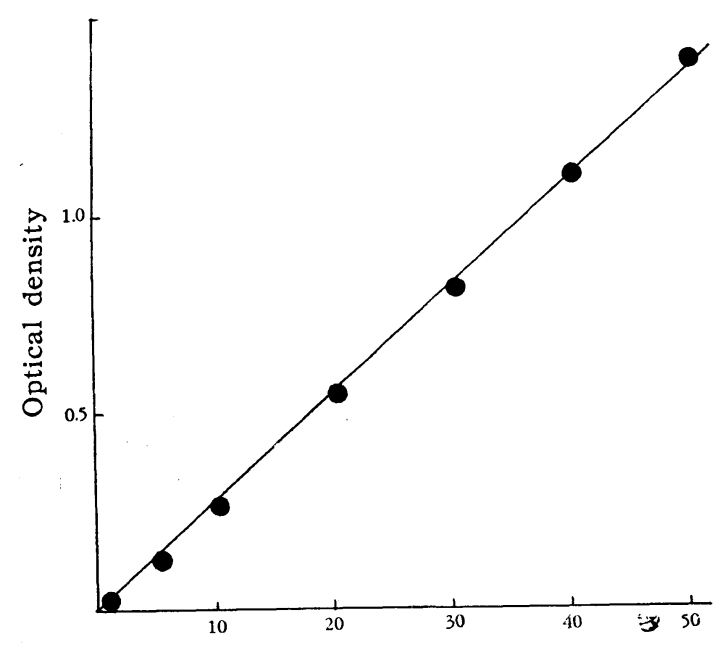

$\beta$-Naphthol concentration in $\mu \mathrm{g}$

Fig. 1. Standard curve for the determination of $\beta$-naphthol.

As shown in Fig. 1, a straight line was obtained between 0 and $50 \mu \mathrm{g}$ of $\beta$-naphthol.

Optimum $\mathrm{pH}$ for the esterase activity The influence of $\mathrm{pH}$ on the esterase activity of homogenate to $\beta$-naphthyl acetate were studied by changing $\mathrm{pH}$ of the phosphate buffer.

It is shown in Fig. 2, that the optimum $\mathrm{pH}$ range is from 6.8 to 7.0. Non-enzymatic decomposition of substrate was remarkable at alkaline $\mathrm{pH}$. This is mainly

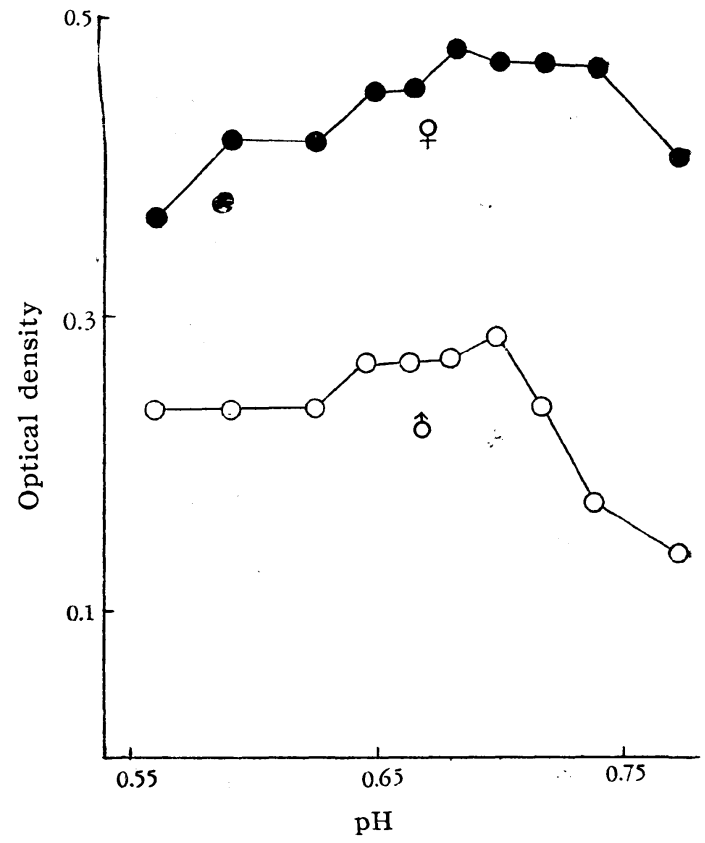

Fig. 2. Influence of $\mathrm{pH}$ on the esterase activity. Insect; Oyama colony. Homogenate concentration; adult/5 $\mathrm{ml}$ buffer. Reaction time; $5 \mathrm{~min}$.

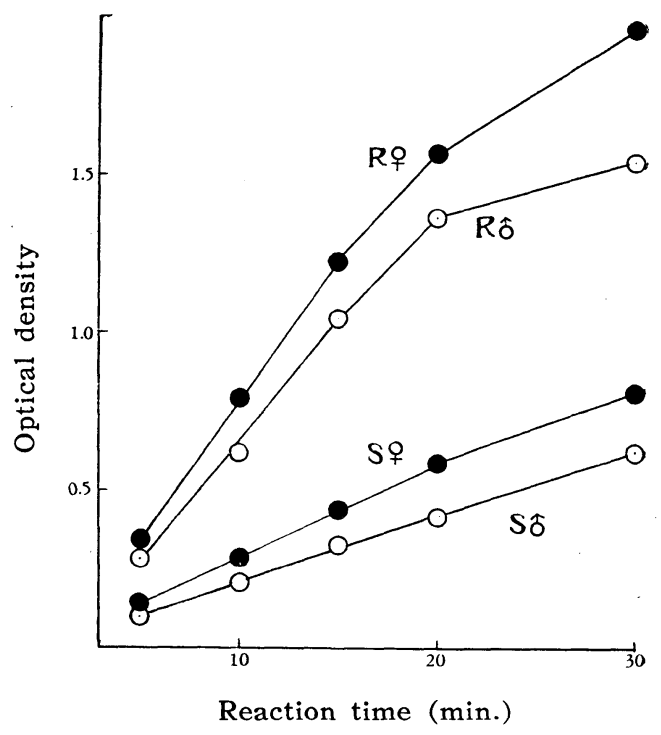

Fig. 3. Influence of reaction time on the esterase activity. Insect; $\mathrm{R}$ and $\mathrm{S}$ indicates Oyama colony and Konosu colony respectively. Homogenate concentration; adult $/ 5 \mathrm{ml}$ buffer of $\mathrm{pH}$ 7.6. 
influenced by remarkable coupling of diazotized red color product.

Reaction time The enzyme solution was incubated with substrate-buffer solution for various period, and the relation between reaction time and rate of hydrolysis were studied. The results obtained are given in Fig. 3.

The esterase activity increases linearly with a period of incubation until $20 \mathrm{~min}$. both in the malathion resistant and susceptible leafhopper. But in the malathion resistant Oyama colony increase in the activity becomes slower after $20 \mathrm{~min}$. The malathion resistant leafhopper is more active than the susceptible one and the female is more active than the male.

Effect of enzyme concentration on the esterase activity The relationship between the esterase activity and the concentration of the enzyme were investigated. The results obtained are shown in Fig. 4.

As shown in Fig. 4, the esterase activity increases linearly with increase of the

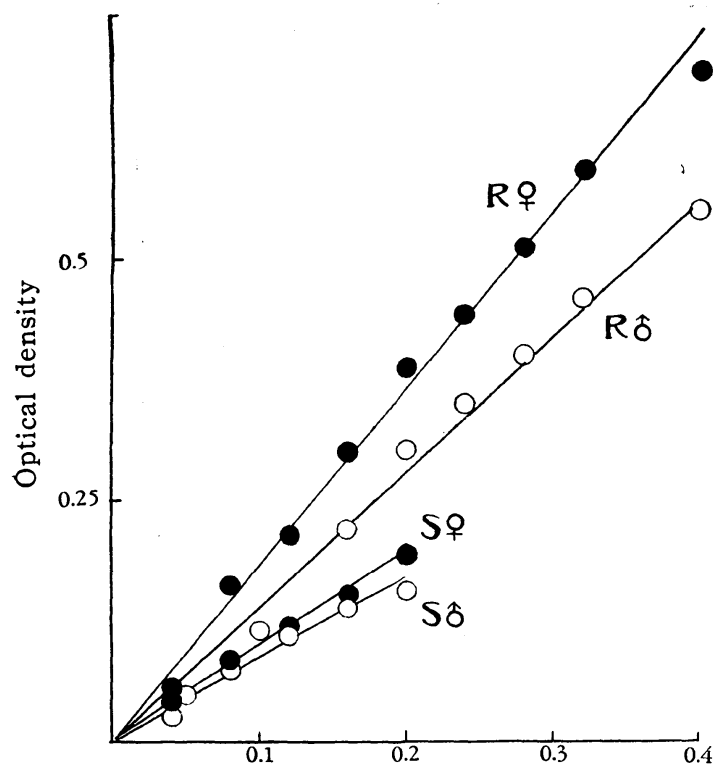

Homogenate concentration (adults/tube)

Fig. 4. Influence of enzyme concentration on the esterase activity. Insect; $R$ and $S$ indicate Oyama and Konosu colony respectively. Reaction time; $5 \mathrm{~min}$. $\mathrm{pH} ; 7.0$. enzyme concentration. Degree of activity in the malathion resistant leafhopper is higher than that in the susceptible one.

Changes of the esterase activity during larval growth and difference in sexes The esterase activity was assayed in larvae and adults of malathion resistant Ösone colony and susceptible Konosu colony. The results obtained are shown in Fig. 5.

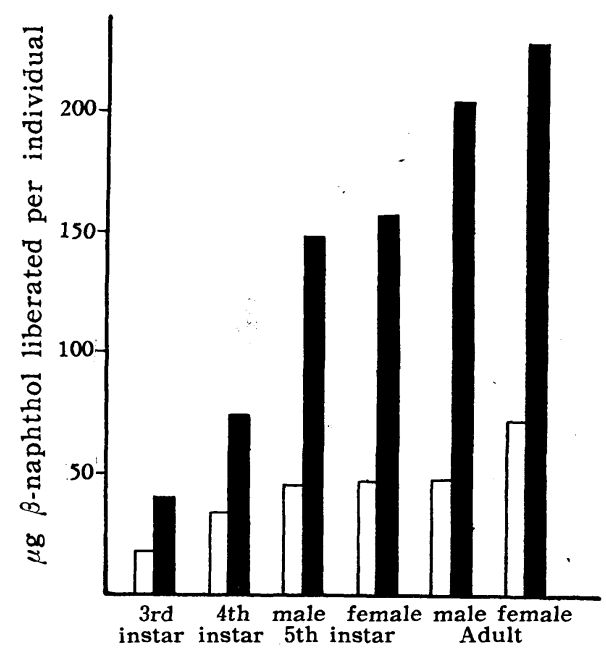

Fig. 5. The esterase activity in larvae and adults of the leafhopper. Solid bars are malathion resistant Ōsone colony, hollow bars susceptible Konosu colony. Reaction time; 20 min. $\mathrm{pH} ; 7.0$.

In larvae, the esterase activity is increased according to the progress of instars. Adults have higher activity of esterase than larvae. In 5 th instar larvae and adults, the esterase activity in female is more than that in male. These differences among instars, stages or sexes in esterase activity are caused not only by the increased body weight but by other factors such as the nature of enzyme proteins. The increased rate of activity with changes in the instar and the stage is higher in the malathion resistant leafhopper than in the susceptible one. In malathion resistant leafhopper, the esterase activity shows remarkable differences between 5 th instar larvae and adults. 
No such a wide difference is found in the susceptible leafhopper.

Relation between the esterase activity and resistance to organophosphorus insecticide As mentioned above, the esterase activity showed the significant difference between the malathion resistant leafhopper and the susceptible one. Still, it was not clarified whether the variation in its activity was connected with the development of malathion resistance of the leafhopper or other insecticide resistance. Then further investigation was made to ascertain the esterase activity and susceptibility to malathion and methyl parathion with the colonies collected from various localities.

Table 1 shows the esterase activity of various colonies. The highest activity was observed in Oyama colony, next was Nakagawahara, these were followed by Kuroda and Okayama colony.

Table 1. Difference of the esterase activity among colonies.

\begin{tabular}{l|c|c}
\hline \multicolumn{1}{c|}{ Colony } & $\begin{array}{c}\text { Homogenate } \\
\text { concentration } \\
\text { (adult/buffer) }\end{array}$ & $\begin{array}{c}\text { Optical } \\
\text { density }\end{array}$ \\
\hline Oyama & & 2.000 \\
Kuroda & & 0.775 \\
Koga & $1 / 5$ & 0.137 \\
Soka & & 0.182 \\
Kasukabe & & 0.103 \\
Okonosu & & 0.166 \\
Okayama & \multirow{2}{*}{$1 / 10$} & 0.673 \\
Nakama & & 1.229 \\
& &
\end{tabular}

Reaction time; $20 \mathrm{~min} . \mathrm{pH} ; 7.0$.

The LD-50 of individual colonies to malathion and methyl parathion is shown in Table 2. Tables 1 and 2 show that there is a high correlation between the esterase activity and $\mathrm{LD}-50$ to malathion.

In the Oyama colony, which gave the highest activity of the esterase among all the test colonies, LD-50 to methyl parathion was lower than in Nakagawahara or in the Okayama colony. No relationship between the esterase activity and the LD-50 to methyl parathion was found. Consequently, it is considered that the
Table 2. LD-50 of malathion and methyl parathion applied topically on the leafhopper female adults of various colonies. (OzAKI and KURosu, in press)

\begin{tabular}{l|c|c}
\hline \multirow{2}{*}{ Colony } & \multicolumn{2}{|c}{$\begin{array}{r}\text { LD-50 in } \mu \text { g per gram } \\
\text { of body }\end{array}$} \\
\cline { 2 - 3 } & Marathion & $\begin{array}{c}\text { Methyl } \\
\text { parathion }\end{array}$ \\
\hline Oyama & 10.13 & 48.37 \\
Konosu & 0.65 & 6.84 \\
Okayama & 3.51 & 141.98 \\
Nakagawahara & 12.41 & 319.76
\end{tabular}

striking increase on the esterase activity takes part in malathion resistance of the leafhopper.

The in vitro esterase inhibition with malaoxon and paraoxon The in vitro inhibition experiments to the esterase were carried out with various doses of malaoxon and paraoxon. The relation between the inhibition rate and the amount of inhibitor gave sigmoid curves. From these curves, ID-50 values of malaoxon and paraoxon for esterase were obtained as Table 3.

- The ID-50 of malaoxon ranged from 3.57 $\times 10^{-7} \mathrm{M}$ to $5.01 \times 10^{-7} \mathrm{M}$ and that of paraoxon ranged from $7.87 \times 10^{-10} \mathrm{M}$ to $8.63 \times$ $10^{-10} \mathrm{M}$. The ID-50 values of malaoxon and paraoxon for the esterase of malathion resistant colony were approximately the same as those of susceptible colony.

The in vitro esterase inhibition with eserin and DFP In the susceptible Konosu colony and the malathion resistant Ōsone

Table 3. ID-50 of malaoxon and paraoxon for the esterase.

\begin{tabular}{|c|c|c|c|}
\hline \multirow{2}{*}{ Colony } & \multirow{2}{*}{ Sex } & \multicolumn{2}{|c|}{ ID-50 (M) } \\
\hline & & Malaoxon & Paraoxon \\
\hline $\begin{array}{l}\mathrm{R} \\
\mathrm{R} \\
\mathrm{S}\end{array}$ & $\begin{array}{l}\hat{\delta} \\
\text { 우 } \\
\text { 오 }\end{array}$ & $\begin{array}{l}3.57 \times 10^{-7} \\
4.16 \times 10^{-7} \\
5.01 \times 10^{-7}\end{array}$ & $\begin{array}{l}7.87 \times 10^{-10} \\
8.63 \times 10^{-10} \\
8.24 \times 10^{-10}\end{array}$ \\
\hline
\end{tabular}

Insect; $\mathrm{R}$ and $\mathrm{S}$ are Oyama and Konosu colony respectively. Homogenate concentration; female of $R, 1 / 20$, male of $R$ and female of $S, 1 / 10$. Reaction time; $20 \mathrm{~min}$. Incubation with inhibitor; the homogenate was incubated with each final concentration of inhibitor for $30 \mathrm{~min}$ at $37^{\circ} \mathrm{C}$. 


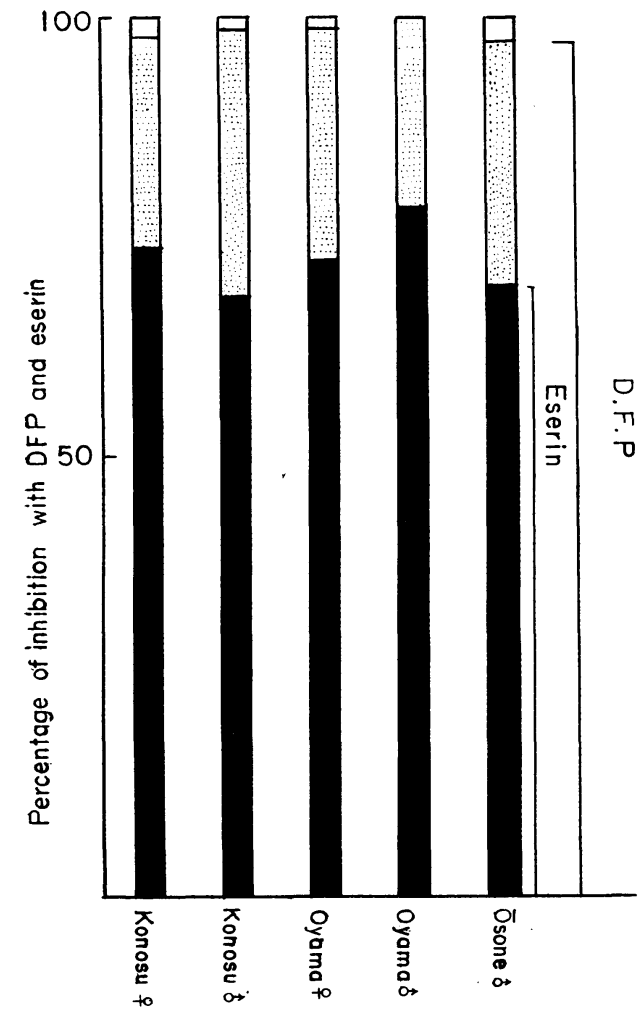

Fig. 6. Inhibition rate of the esterase activity with eserin and DFP. Homogenate concentration; female of Oyama colony, $1 / 20$, male of Oyama and Ōsone colony, $1 / 10$, female of Konosu colony, $1 / 5$, male, $1 / 3$. Reaction time; $20 \mathrm{~min}$. $\mathrm{pH} ; 7.0$. Incubation with inhibitor; as in explanation of Table 3 .

and Oyama colony, in vitro inhibition experiments for the esterase were conducted with eserin and DFP. The experimental results are given in Fig. 6.

The inhibition rate by $10^{-5} \mathrm{M}$ eserin was ranged from 66 per cent to 78 per cent. This value of inhibition rate is comparable to that of kidney, pancreas and liver of dog and human (Nachlas and Seligman, 1949). The esterase was inhibited more than 97 per cent by DFP at $10^{-5} \mathrm{M}$. Significant differences in inhibition by DFP or eserin among the colonies were not obtained.

\section{DISCUSSION}

The method of naphthyl acetate esterase determination and the difference between susceptible and organophosphorus insecticide resistant leafhopper were studied in this report. The method of determining esterase activity by using naphthyl esters as substrate was established by $\mathrm{N}_{\text {ACHLAS }}$ and Seligman in the mammalian tissue homogenates. KoIKe (in press) found that this method is so sensitive and specific for insects, and applicable to small insects such as aphid. VAN Asperen (1963) reported a method that esterase activities can be measured in the range of $10 \mu \mathrm{g}$ and 100 $\mu \mathrm{g}$ of the housefly, and he applied it to the determination of the esterase activity in individual adults of spider mite (Tetranychus urticae).

From the results reported in this paper it was found optimum that the enzyme concentration was from 5 to $20 \mathrm{ml}$ of buffer per adult and the reaction time was from 5 to $20 \mathrm{~min}$. The increase of esterase activity was connected closely with the development of resistance to malathion in the leafhopper, but not with that to methyl parathion.

As above, the esterase activity in the leafhopper is assayed speedily and individually, and increase remarkably in the malathion resistant colony. By determining the esterase activity it may be able to examine whether or not a leafhopper develops malathion resistance, and this method has the biological significances that the resistance mechanisms or the heredity of the resistance to malathion may be analyzed enzymologically.

According to the results obtained by van Asperen, no significant differences were found between the esterase activities of susceptible and $o-p$ resistant houseflies when $\alpha$ - and $\beta$-naphthyl acetate used as substrate. But using $\alpha$-naphthyl acetate, the non-eserin inhibited esterase was more active in $o-p$ resistant strain than that in susceptible strain. No such difference was found when $\beta$-naphthyl acetate was used. While the esterase activity in the leafhopper was much higher for a malathion resistant colony than for a susceptible one, the ratio of the non-eserin inhibited 
esterase activity to total esterase activity in both colonies of susceptible and malathion-resistance gave a somewhat similar activity when $\beta$-naphthyl acetate was used as substrate.

KoJima et al (1963) suggests that the resistance mechanisms of insects to malathion are divided into following two types, that is, one caused with the increase of phosphatase activity and the decrease of $B$ esterase activity, as in the case of housefly; the other caused with the increase of carboxy esterase activity as in the case of mosquitoes. They suggest that the resistance mechanisms to malathion in the leafhopper belong to the latter case.

By using a selective inhibitor, esterases were separated into cholinesterase, Besterase and A-esterase. The ratio of $\mathrm{B}$ esterase activiiy in malathion resistant leafhopper was not seem to be different from that of susceptible one (see Fig. 6). As pointed by Kojima et al, the resistance mechanisms to malathion in the leafhopper differ markedly from that of the $o-p$ resistant housefly, in which B-esterase activity becomes lower than in the susceptible one (van Asperen, 1962). This dissimilation on the resistance mechanisms is due to the differences in the species of insects.

In this insect, activity of cholinesterase is not altered by the development of resistance to malathion (KoJima et al, 1963). But as shown in Figs. 5 and 6 , the cholinesterase for the malathion resistant leafhopper was more active than that for susceptible leafhopper. Conclusively, in the malathion resistant leafhopper, the esterases hydrolysing malaoxon or malathion are higher activity; on the other hand the activities of these esterase are attended by increases of cholinesterase and other esterases activities.

The results reported here show that the increase of the naphthyl acetate esterase activity affects the development of malathion resistance in the leafhopper; therefore it is suggested that the increased parts of the esterase activity in malathion resistant leafhopper may include the esterase hydrolyzing maloxon or malathion.

\section{SUMMARY}

Optimum conditions for determination of esterase in the green rice leafhopper was determined by using $\beta$-naphthyl acetate as substrate, and the difference between esterase activity of susceptible and organophosphorus resistant leafhopper was examined.

This method was very sensitive, and it was found that the optimum concentration of homogenate was from $5 \mathrm{ml}$ to $20 \mathrm{ml}$ of buffer per adult and the reaction time was from $5 \mathrm{~min}$. to $20 \mathrm{~min}$. In larva, the esterase activity increased with age, the adult generally showed higher activity than larva and female was higher than male.

The malathion resistant leafhopper had significantly higher activity of esterase than the susceptible one. Increase in esterase activity was closely correlated with malathion resistance. The ID-50 values of malaoxon and paraoxon for the esterase of malathion resistant colony were approximately the same as those of the susceptible colony. In both the resistant and susceptible leafhopper, the esterase activity consisted of cholinesterase and Besterase. The ratio of each esterase activity to total esterase activity was not differed between the resistant and the susceptible leafhopper.

\section{REFERENCES}

Asperen, K. van. (1962) J. Ins. Physiol. 8: 401〜 406.

KolKe, H. (1964) In preparation.

Kojima, K., S. Kitakata, A. Shinno, and $T$. Yoshil (1963) Botyu-Kagaku 28: 13 17 (in Japanese with English summary)

Kojima, K., T. IshizukA, and S. Kitakata, (1963) Botyu-Kagaku, 28: 17 25. (in Japanese with English summary)

Nachlas, M. M. and A. M. Seligman, (1949). J. B. C. 181: 343 3j̄5.

OzAKI K. (1964) In preparation.

OzAKI, K. and Y. Kurosu, (1964) In preparation. 
摘 要

ツマグロヨコバイに打けるナフチルアセテートエステラーゼ，とくに 有機りん剂に抵抗性の個体群に抽ける異常な高活性について

尾 猗 幸三郎・小池 久義

農業技術研究所病理昆虫部

基質に $\beta$-naphthyl acetate を用いてッマグロヨコ バイのエステラーゼ活性を測定する方法を検討し，この エステラーゼ活性が有機りえ剤に抵抗性の個体群と感受 性の個体群とで異なるかどうかを調べた。

基質に $\beta$-naphthyl acetate を用いた場合,エステラ 一ゼ活性の測定感度は極めて高く, 成虫の 1 個体を 5 $\mathrm{ml}$ から $20 \mathrm{ml}$ のりえ酸緩衝液で磨砕した酵素液で 測 定することができ，また反応時間は 5 分から 20 分の間 で十分であった。なお最適 $\mathrm{pH}$ は 6.8 から 7.0 の範 囲であった。

幼虫のエステラーゼ活性は生育するにつれて増大し た。成虫のエステラーゼ活性は幼虫より高く, 雌は雄よ り高かった。

マラソンに抵抗性の個体群では, 感受性の個体群に比 ベてエステラーゼ活性は有意に高かった。各地から採集
した個体群の間にはエステラーゼ活性に顕著な違いがみ られたが,エステラーゼ活性とマラソンに対する LD-50 との間には高い相関関係があった。しかし，メチルバラ チオンに対する LD-50 との間には同様な関係はみられ なかった。ツマグロヨコバイにおけるナフチルアセテー トエステラーゼ活性の増大はマラソンに対する抵抗性の 発達に関係するものと考える。

ナフチルアセテートエステラーゼに対するマラオク ソンとパラオクソンの ID-50 はマラソンに抵抗性の個 体群と感受性の個体群との間で差がなかった。ナフチル アセテートエステラーゼ活性はコリンエステラーゼと B-エステラーゼからなっていた。合計エステラーゼ活性 に対する各エステラーゼ活性の割合は抵抗性個体群と感 受性個体群の間で差がなかった。 